\title{
FUEL BURN-UP DISTRIBUTION AND TRANSURANIC NUCLIDE CONTENTS PRODUCED AT THE FIRST CYCLE OPERATION OF AP1000
}

\author{
Jati Susilo, Jupiter Sitorus Pane \\ Center for Nuclear Reactor Technology And Safety \\ PUSPIPTEK Complex O.B.80, Tangerang Selatan, 15310 \\ E-mail: shushilo@batan.go.id \\ Diterima editor: 15 April 2016 \\ Diperbaiki: 15 Juni 2016 \\ Disetujui untuk publikasi: 22 Juni 2016
}

\begin{abstract}
FUEL BURN-UP DISTRIBUTION AND TRANSURANIC NUCLIDE CONTENTS PRODUCED AT THE FIRST CYCLE OPERATION OF AP1000. AP1000 reactor core was designed with nominal power of $1154 \mathrm{MWe}$ (3415 MWth), operated within life time of 60 years and cycle length of 18 months. For the first cycle, the AP1000 core uses three kinds of $\mathrm{UO}_{2}$ enrichment, they are $2.35 \mathrm{w} / \mathrm{o}, 3.40 \mathrm{w} / \mathrm{o}$ and $4.45 \mathrm{w} / \mathrm{o}$. Absorber materials such as $\mathrm{ZrB}_{2}$, Pyrex and Boron solution are used to compensate the excess reactivity at the beginning of cycle. In the core, U-235 fuels are burned by fission reaction and produce energy, fission products and new neutron. Because of the U-238 neutron absoption reaction, the high level radioactive waste of heavy nuclide transuranic such as $\mathrm{Pu}, \mathrm{Am}, \mathrm{Cm}$ and $\mathrm{Np}$ are also generated. They have a very long half life. The purpose of this study is to evaluate the result of fuel burn-up distribution and heavy nuclide transuranic contents produced by AP1000 at the end of first cycle operation (EOFC). Calculation of $1 / 4$ part of the AP1000 core in the 2 dimensional model has been done using SRAC2006 code with the module of COREBN/HIST. The input data called the table of macroscopic crossection, is calculated using module of PIJ. The result shows that the maximum fuel assembly (FA) burn-up is $27.04 \mathrm{GWD} / \mathrm{MTU}$, that is still lower than allowed maximum burn-up of $62 \mathrm{GWD} / \mathrm{MTU}$. Fuel loading position at the center/middle of the core will produce bigger burn-up and transuranic nuclide than one at the edges the of the core. The use of IFBA fuel just give a small effect to lessen the fuel burn-up and transuranic nuclide production.
\end{abstract}

Keywords: Fuel Burn-Up, Transuranic, AP1000, EOC, SRAC2006

\begin{abstract}
ABSTRAK
DISTRIBUSI BURN-UP DAN KANDUNGAN NUKLIDA TRANSURANIUM YANG DIHASILKAN BAHAN BAKAR PADA SIKLUS OPERASI PERTAMA TERAS AP1000. Reaktor AP1000 didesain dengan daya nominal $1154 \mathrm{MWe}$ (3415 MWth), mampu beroperasi selama umur reaktor sekitar 60 tahun dan memiliki panjang tiap siklus sekitar 18 bulan. Pada siklus operasi pertama, teras AP1000 menggunakan tiga jenis pengkayaan bahan bakar $\mathrm{UO}_{2}$ yaitu 2,35 w/o, 3,40 w/o dan 4,450 w/o. Penyerap neutron ZrB $B_{2}$, Pyrex dan larutan Boron digunakan sebagai kompensasi reaktivitas lebih pada awal siklus. Di dalam teras reaktor, bahan bakar U-235 mengalami pembakaran melalui reaksi fisi yang akan menghasilkan energi, produk fisi dan neutron baru. Karena adanya reaksi serapan neutron oleh U-238 maka reaktor juga menghasilkan limbah radioaktif tingkat tinggi berupa nuklida transuranium yang mempunyai waktu paruh sangat panjang seperti $\mathrm{Np}$, Pu, Am, dan Cm. Dalam penelitian ini dilakukan analisis hasil perhitungan distribusi burn-up bahan bakar dan kandungan nuklida transuranium yang dihasilkan oleh teras AP1000 saat akhir siklus operasi pertama. Perhitungan model geometri 2 dimensi teras AP1000 bentuk 1/4 bagian dilakukan dengan paket program SRAC2006 modul COREBN/HIST. Sedangkan input data berupa tabel tampang lintang makroskopik diperoleh dari perhitungan dengan modul PIJ. Hasil prhitungan menunjukkan bahwa burn-up perangkat bahan bakar (Fuel Assembly, FA) tertinggi adalah sebesar 27,04 GWD/MTU dan ini masih jauh lebih rendah dari batas maksimum burn-up yang diijinkan yaitu $62 \mathrm{GWd} / \mathrm{MTU}$. Posisi pemuatan perangkat bahan bakar di bagian tengah teras akan menghasilkan burn-up dan nuklida transuranium yang lebih besar dibandingkan dengan ditepi teras. Penggunaan bahan bakar Integrated Fuel Burnable Absorber hanya sedikit berpengaruh terhadap penurunan burn-up dan nuklida transuranium yang dihasilkan.
\end{abstract}

Kata kunci: Fuel burn-up, kandungan nuklida transuranium, AP1000, siklus operasi pertama, SRAC2006 


\section{INTRODUCTION}

Pressurized Water Reactor (PWR) is one type of pressurized reactors that uses light water $\left(\mathrm{H}_{2} \mathrm{O}\right)$ as moderator as well as coolant. The moderator is pressurized to avoid boiling. In general, PWR reactors use uranium oxide $\left(\mathrm{UO}_{2}\right)$ with low enrichment of between $2 \sim 5 \mathrm{w} / \mathrm{o}$. As a latest available design of the PWR reactors (Generation III + ), AP1000 reactor is designed to produce electrical power of about $1154 \mathrm{MWe}$ (3415 MWth), with a cycle length of about 18 months and reactor life time of 60 years. AP1000 core, for the first operating cycle (first cycle), uses three kinds of $\mathrm{UO}_{2}$ fuel enrichment i.e. $2.35 \mathrm{w} / \mathrm{o}, 3.40 \mathrm{w} / \mathrm{o}$ and $4.50 \mathrm{w} / \mathrm{o}$. In addition to fuel, as a reactivity compensation at the beginning of the cycle (BOC), AP1000 uses neutron absorbing material $\mathrm{ZrB}_{2}$, Pyrex and a solution of Boron [1].

In the reactor core, fission reaction between U-235 fuel and neutron will generate energy, fission products (FP) and new neutrons. Moreover, since the neutron reacts with U-238 through absorption reaction, the high-level radioactive waste transuranic nuclides such as $\mathrm{Pu}, \mathrm{Am}, \mathrm{Cm}$ and $\mathrm{Np}$, will be produced. They have a very long half-lives time. At the end of the operating cycle, the fuel will contain with uranium residue of fuel burning, FP and transuranic nuclide.

Countries like European countries, USA, Japan, China that have a reprocessing plant will be able to reprocess of their spent fuel [2-4]. Indeed, uranium and plutonium are separated from other nuclides, and then assemblied into new nuclear fuel. The fuel from this process is called the Mixed Oxide Fuel (MOX) [5]. The re-use of uranium and plutonium from the residue of the fuel provide the following benefits i.e. the effectiveness of the using of nuclear fuel resources and reducing waste load into the environment. Whereas the high-level radioactive waste of other transuranic ( $\mathrm{Np}, \mathrm{Am}$ and $\mathrm{Cm})$ was treated at long-term storage.

The burn-up of ${ }^{235} \mathrm{U}$ can be determined through the calculation of the distribution of fuel burnup at End of Cycle (EOC). By knowing the fuel burn-up, it will be easier to perform the fuel management both within the core to the establish equilibrium core [6] and out-core to provide the data of recycling, to determine criticality of spent fuel storage, and as the data for further fuel material development and others [7-10]. Research on burn-up and content of transuranic nuclides on the PWR core fuel has also been carried out, among others, European Pressurized Water Reactor (EPR) using Mure computer code [11], changing of fissile and non-fissile mass materialon on PWR $1000 \mathrm{MWe}$ core using ORIGEN-ARP 5 [12], and the effect of uncertainty of the calculation of fuel burn-up PWR using SCALE 6.0 [13].

While research on burn-up and content of transuranic nuclides in the fuel of AP1000 core in the End of First Cycle (EOFC) operation has never been performed. Therefore, this paper would report the analysis of the distribution of fuel burn-up and content of transuranic nuclides produced by AP1000 core at the EOFC with the purpose to evaluate the calculation result model.

The calculation of fuel burn-up was done using SRAC2006 computer code [14] using the module of COREBN/HIST through modeling a $1 / 4$ section of the core. In additional to fuel burn-up calculation, the module of COREBN/HITS can also be used for fuel management of various configuration (multi-dimensional) of reactor core based on the finite difference solution of the diffusion equation and the infixation of macroscopic cross section. The COREBN/HITS module has been used to conduct an evaluation of the management's calculation of RSG-GAS core and got a good results [15]. One of the input data called macroscopic cross section of the fuel, as function of burn-up, is obtained from PIJ module's calculation. Module PIJ, a part of the SRAC 2006 code, is based on neutron transport theory using neutron collision probability method approach in solving the Boltzman equation. Through this analysis, it is expected that the characteristics of fuel burn-up and content of transuranic nuclides in the spent fuel, produced at the end of the operating first cycle AP1000 core, could be recognized

\section{METHODOLOGY}

\section{Model of Fuel Assembly And Reactor Core}

In order to determine the macrosscopic crossection, then the calculation using $1 / 4$ model geometry of fuel assembly calculation is done using SRAC2006 code of PIJ module. In the first 
operation cycle, AP1000 core was composed by various types of fuel assemblies (FA) that consist of Fuel Standard, Integrated Fuel Burnable Absorber (IFBA) and Pyrex. Then the models of the fuel assemblies are divided into 7 types as shown in Table 1.

Table 1. Material Composition of Each Fuel Assembly [1].

\begin{tabular}{clccc}
\hline No. & $\begin{array}{l}\text { Name of Fuel } \\
\text { Assembly }\end{array}$ & $\begin{array}{c}\text { UO2 } \\
\text { Enrichment }\end{array}$ & $\begin{array}{c}\text { Number of } \\
\text { IFBA }\end{array}$ & $\begin{array}{c}\text { Number of } \\
\text { Pyrex }\end{array}$ \\
\hline 1 & FA-1 & 2.35 & - & - \\
2 & FA-1a & 2.35 & 28 & - \\
3 & FA-2 & 3.40 & 88 & 24 \\
4 & FA-2a & 3.40 & 28 & 24 \\
5 & FA-2b & 3.40 & 44 & 24 \\
6 & FA-3 & 4.45 & 88 & 12 \\
7 & FA-3a & 4.45 & 72 & 24 \\
8 & FA-3b & 4.45 & 88 & 9 \\
9 & FA-3c & 4.45 & 112 & - \\
\hline
\end{tabular}

The modeling of AP1000 reactor core also uses a $1 / 4$ model geometric of the reactor core with boundary condition reflected in the vertical and horizontal direction, as shown in Figure 1. The first operating cycle of AP1000 reactor core is composed of 157 fuel assemblies with 3 groups of fuel enrichment i.e. $2.35 \mathrm{w} / \mathrm{o}, 3.40 \mathrm{w} / \mathrm{o}$, and $4.45 \mathrm{w} / \mathrm{o}$ in which each group consists of 56,52 and 52 unit, respectively. As a result, the amount of each fuel assemblies in the model-quarter of the core is 17,15 and 14 units. Fuel assemblies positioned at the X-Y axis direction is modeled by assuming $1 / 2$ of the normal volume. In addition to the fuel, on the edge of the core from the inside to outside composed of baffle reactor, light water coolant, reactor barrel $\left(\mathrm{d}_{\mathrm{in}} / \mathrm{d}_{\text {out }} 339.725 \mathrm{~cm} / 349.885 \mathrm{~cm}, \mathrm{SS} 304\right.$ material $)$, coolant, and the reactor vessel $\left(\mathrm{d}_{\mathrm{in}} / \mathrm{d}_{\text {out }} 398.8 \mathrm{~cm} / 420 \mathrm{~cm}\right.$, material SS304) wich also modeled for $1 / 4$ section. The calculation of fuel burn-up will be done using COREBN / HIST module. 


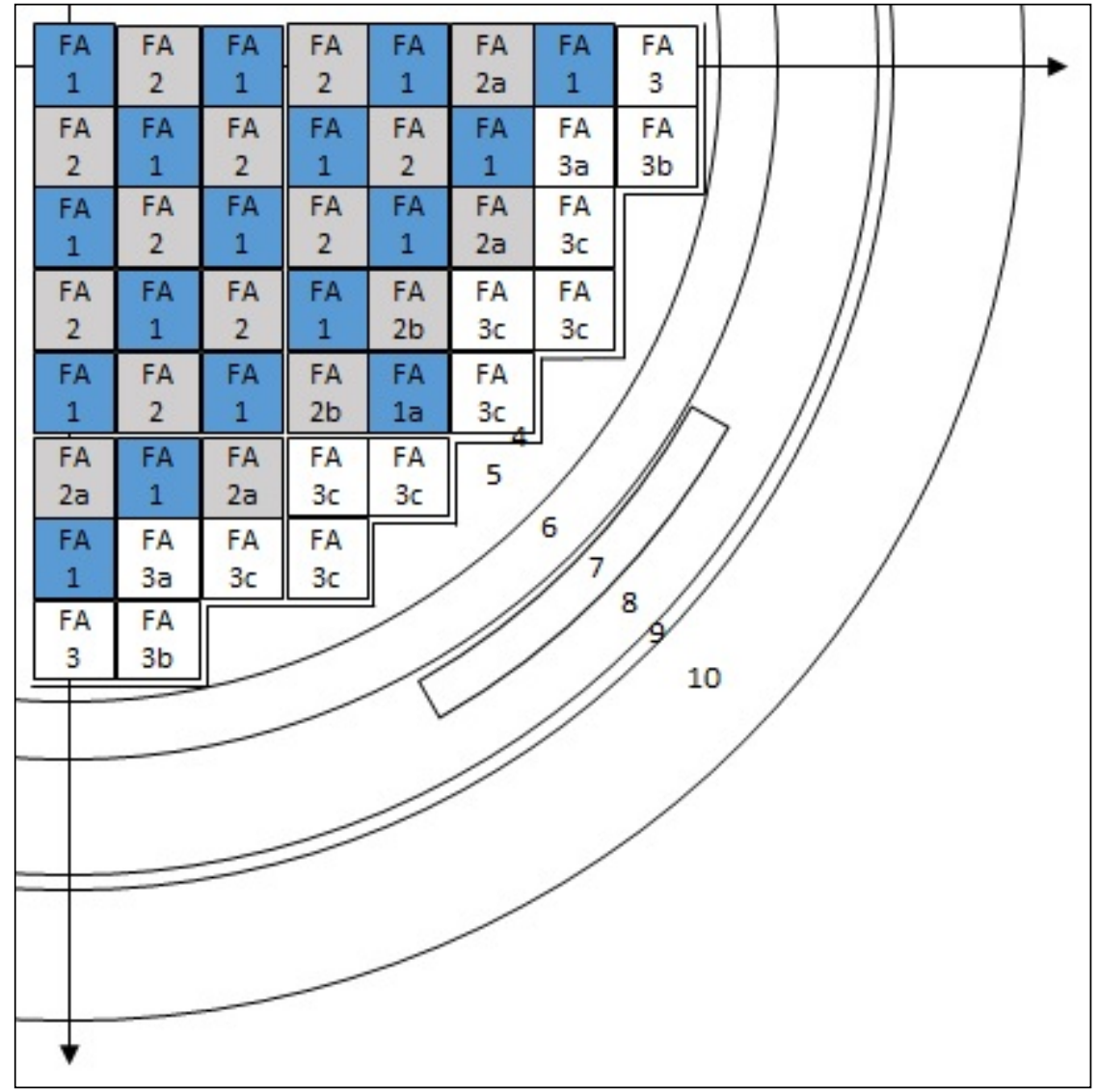

FA 1,2,3 = Fuel Assembly with $\mathrm{UO}_{2} 2.35$ w/o (1), 3.40 w/o (2), and 4.45 w/o (3), 4=Baffle Reactor, 5=Moderator $\mathrm{H}_{2} \mathrm{O}$, 6=Barrel Reactor, $7=$ Neutron Pad, $8=$ Coolant $\mathrm{H}_{2} \mathrm{O}$, 9=Vessel Liner, 10=Vessel Reactor

Figure 1. Distribution of Fuel Assembly at 1/4 Model of AP1000 Core.

\section{Calculation Flowchart}

The calculation of $k$-eff value, fuel assembly burn-up distribution and heavy nuclides transuranic were done using SRAC2006 computer code with the sequence shown in a flowchart in Figure 2. The cross-sectional data used in these calculations is taken from SRACLIB-JDL3.3 by dividing the energy group of 107 into 16 groups.

Calculation of the fuel macroscopic cross section as a function of burn-up is performed on $1 / 4$ of the core fuel assemblies with two-dimensional geometry. The number of burn-up step is divided by 24 steps with unit of MWD / MTU. It equals to $1 \mathrm{E}+2,1 \mathrm{E}+3,2.5 \mathrm{E}+3,5 \mathrm{E}+3,7.5 \mathrm{E}+3,1.0 \mathrm{E}+4,1.25 \mathrm{E}+4$, $1.50 \mathrm{E}+4,1.75 \mathrm{E}+4,2.0 \mathrm{E}+4,2.25 \mathrm{E}+4,2.5 \mathrm{E}+4,2.75 \mathrm{E}+4,3.0 \mathrm{E}+4,3.25 \mathrm{E}+4,3.5 \mathrm{E}+4,3.75 \mathrm{E}+4,4.0 \mathrm{E}+4$, $4.25 \mathrm{E}+4,4.5 \mathrm{E}+4,4.75 \mathrm{E}+4,5 \mathrm{E}+4,5.25 \mathrm{E}+4$, and $5.5 \mathrm{E}+4$. In addition to a burn-up step, another necessary data input for this calculation is a linear power $(1.27286 \mathrm{E}-2 \mathrm{MW} / \mathrm{cm})$, the radius for each lattice fuel, size of the guide tube and Pyrex, as well as the density and temperature of the material composed. The output obtained from this model is fuel assembly macroscopic cross section as a function burn-up.

Calculation of the macroscopic cross section of the non- fuel is performed using the module CITATION against to 2-dimensional of $1 / 4$ geometry of the AP1000 model. Input data required are homogenized macroscopic crossection of the fuel assemblies, temperature and density of the material composed of the core. Output data obtained is a macroscopic cross section of the non-fuel material such as baffles, coolant, barrel reactor, and the reactor vessel.

Input data required to registration materials and geometry of the core using HIST module are number and size of the mesh division for X-Y directions of $1 / 4$ core reactor model, PS file of the crosssectional, U235 and U238 atom density in the fuel assemblies, and naming for each type of the fuel assembly. PS files All of the macroscopic cross-section are result of convertion from PDS file using 
PDStoPS.sh tool. Output data obtained from calculation using HIST module are each fuel assembly tipe and non fuel data stored in history files, for example PWR.BOC.

As the input data required for fuel burn-up calculation of the AP100 reactor core using COREBN module are a history file (PWR.BOC), the position of each material inside the reactor core either the fuel and non-fuel, mesh divition for 2-dimensional geometry of $1 / 4$ AP1000 model, long time operation (12960 hours) and the generated power (3415 MWth). Output obtained from core calculation using COREBN are $k$-eff at the BOC/EOC of core and fuel burn-up for each fuel assembly.

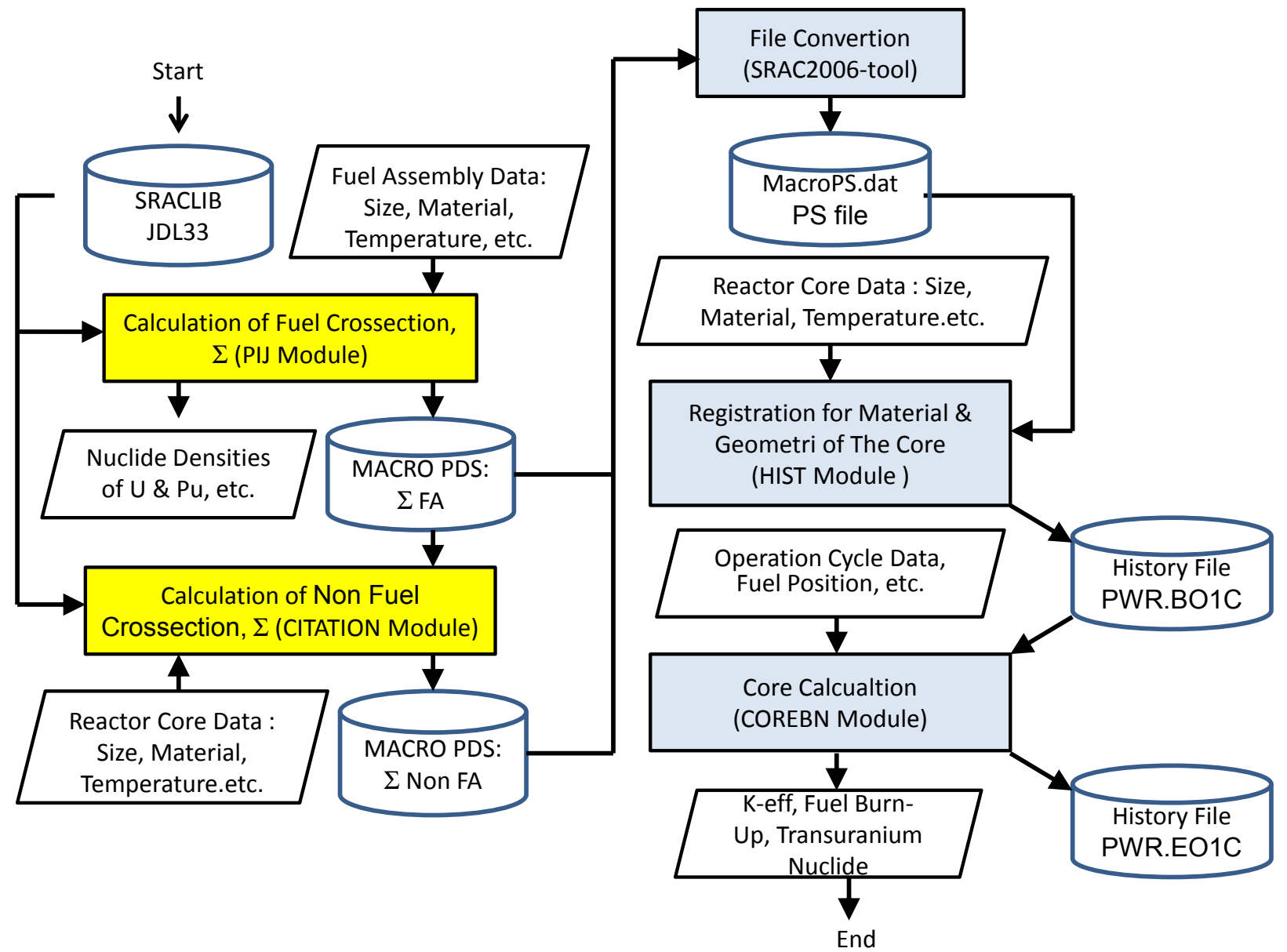

Figure 2. Flowchart for Fuel Burn-up Calculation of AP1000 Core Using SRAC2006.

\section{RESULTS AND DISCUSSION}

Below is described the analysis of the calculation results of the $k$-eff value at BOC / EOC and distribution of fuel burn-up in the AP1000 core as well as changes nuclides such as transuranic, plutonium and uranium in the fuel assembly.

\section{Multiplication Factor}

Table 2 shows the comparison value of $k$-eff for the first operating cycle of AP1000 at hot full power conditions between the reference data and the calculation results using SRAC2006 computer code in the COREBN module. It can be seen that the value of $k$-eff of the AP1000 core at BOC of the calculation results has almost no difference with the reference data that is calculated using the ANC (A Westinghouse Advanced Nodal Computer Code) [1]. The difference was very small, it is around $0.83 \%$. Therefore, it can be said that the k-eff calculation for the AP1000 core using SRAC2006 computer code COREBN modules is valid. 
At EOC of AP1000 core shows has achieved to subcritic condition ( $\mathrm{k}$-eff $<1.00)$, where $\mathrm{k}$-eff $=$ 0.9920837. From Table 2, it also can be seen that $k$-eff at BOC is almost the same as $k$-eff value at EOC. It is because the BOC in the moderator contained solution of boron for compensation of excess reactivity with of amount $1184 \mathrm{ppm}$. Meanwhile, AP1000 at the EOC is no longer a solution of boron remaining in modereator or the concentration of boron almost equal to zero ppm. It is true since during the operation boron which is a strong neutron absorber material will be used to control core reactivity changes caused by changes in the fuel burn-up. So that the boron concentration will be reduced to near zero ppm value at the time of a certain burn-up in which the condition of the k-eff of the core approaching 1.00. So the k-eff for BOC and EOC are almost the same (k-eff $\approx 1.00)$, with different concentration of boron in the moderator.

It has become the basic provisions that to determine the length of the operating cycle of a reactor design then the value of $\mathrm{k}$-eff of the reactor without reactivity control at the EOC should be equal to 1 . It aims is to maintain the stability of the number of neutrons that will be determine the power of the reactor. If it is less than 1.00 , then the power of the reactor core can not be kept constant in a stable condition. Or in other words it can be said that the reactor power will decline so unstable. Likewise for the AP1000 reactor, with a cycle length of about 18 months and power $3411 \mathrm{MW}$, then the reactor in condition without solution of boron and fully-up control rod cluster assemblies, then the value of k-eff at the EOC should be close to 1.00 .

Table 2. Comparison $k$-eff Value of AP1000 Core at First Cycle

\begin{tabular}{lcc}
\hline & BOC & EOC \\
\hline Calculation & 1.0083218 & 0.9920837 \\
Reference Data [1] & 1.00 & n.a. \\
Defferences (\%) & 0.0083218 & n.a. \\
& $(0.83 \%)$ & \\
\hline
\end{tabular}

\section{Fuel Burn Up Distribution}

Figure 3 shows the distribution of fuel assembly burn-up calculated using SRAC2006 computer code with the $1 / 4$ shape of reactor core model of the first core of AP1000 at the end of operating cycle. The first row shows the name of fuel assemblies, and the second and the third, describe the size of the burn-up fuel assemblies in units of percent loss of uranium-235 (\%U-235) and the GWD/MTU, respectively. It can be seen from the figure that the highest burn- up $\left(75.87 \%{ }^{235} \mathrm{U}\right.$ or 27.04 $\mathrm{GWD} / \mathrm{MTU})$ is generated by the fuel assemblies with enrichment $\mathrm{UO}_{2} 2.35 \mathrm{w} / \mathrm{o}(\mathrm{FA} 1-13$ ) at the position of D-8. This value is still below the maximum burn-up value allowed, i.e. $62.00 \mathrm{GWD} / \mathrm{MTU}$. The burn-up standard fuel of $\mathrm{UO}_{2}$ with enrichment of 2.35 w/o without IFBA and Pyrex (FA1) was very plat. The average burn-up of FA1 is $25.02 \mathrm{GWD} / \mathrm{MTU}$, with the highest and the lowest value are $26.30 \mathrm{GWD} / \mathrm{MTU}$ and $21.93 \mathrm{GWD} / \mathrm{MTU}$, respectively. FA1a that consist of $\mathrm{UO}_{2}$ fuel element with enrichment 2.35 w/o with 28 IFBA have an average burn-up of 18.86 GWD/MTU. Indeed, although FA1a and FA1 have the same enrichment (2.35\%), but FA1 yield an average burn-up higher than FA1a, or with margin of about $6.16 \mathrm{GWD} / \mathrm{MTU}$. This result is understanable since the FA1 a contains absorber material. Meanwhile, FAla is located at the edge of the core which generally get lower thermal neutron flux compared with the position in the middle of the core. FA1 and FA1a fuel assembly will not used for the next cycle operation (2nd cycle) of AP1000.

Fuel assembly with enrichment of 3.40 w/o divided into three types, they are FA2 (88IFBA, 24Pyrex), FA2a (28IFBA, 24Pyrex) and FA2b (44IFBA, 24 Pyrex). FA2 has an average burn-up of 23.10 GWD/MTU wth the highest and lowest burn-up value are 24.34 GWD/MTU (FA2-13, position G-12) and 21.93 GWD/MTU (FA2-1, position G-8), respectively. FA2a have an average burn-up of 24.48 GWD/MTU with the the highest burn-up value of $26.30 \mathrm{GWD} / \mathrm{MTU}$ (FA2a-15, position H-13) and the lowest was $22.75 \mathrm{GWD} / \mathrm{MTU}$ (FA2a-9, position C-10). And, FA2b have an average burn-up of 23.01 GWD/MTU with the the highest burn-up value of $23.06 \mathrm{GWD} / \mathrm{MTU}$ (FA2b-14, position E12) and the lowest burn-up value of $22.96 \mathrm{GWD} / \mathrm{MTU}$ (FA2b-12, position D-11). This result show that the burn-up of fuel assemblies with enrichment of 3.40 w/o also was almost flat although their 
location are at the edge or center position in the core. This fact was understanable since the fuels contain the absorber material in the fuel IFBA and Pyrex which make more flat of flux thermal in the core. FA2, FA2a and FA2b fuel assembly usually still be used in the next cycle (2nd cycle) for one cycle to make equilibrium of core.

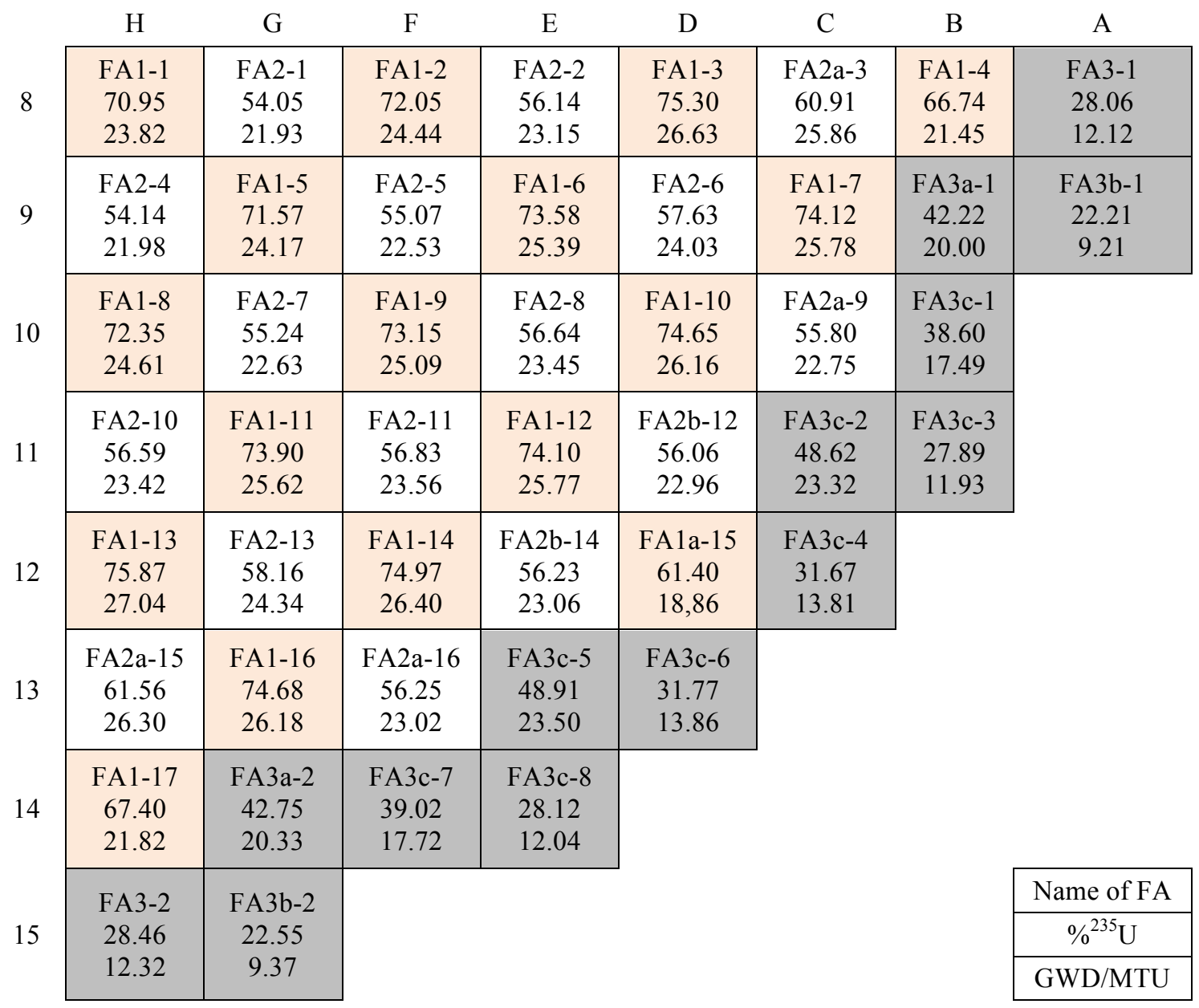

Figure 3. Fuel Burn-Up Distribution at First Cycle of AP1000 Core

Fuel assemblies with enrichment of $\mathrm{UO}_{2} 4.45$ w/o divided into 4 types, they are FA3 (88 IFBA, 12 Pyrex), FA3a (72 IFBA, 24 Pyrex), FA3b (88 IFBA, 9 Pyrex) and FA3c (112 IFBA without Pyrex). Average value of fuel burn-up for FA3, FA3a, FA3b and FA3c are 20.16 GWD/MTU, 12.24 GWD/MTU, 9.29 GWD/MTU, and 16.71 GWD/MTU respectively. Although FA3, FA3a, FA3b and FA3c having the highest enrichment compared to other fuel assembly, but average burn-up is found the lowest. This is because all of the fuel assemblies are located at the edge of the core. As mentioned before that the position of fuel assembly at the edge of the core has a neutron flux thermal which is relative lower then other position in the middle. FA3, FA3a, FA3b and FA3c at the next two operating cycle ( $2^{\text {nd }}$ and $3^{\text {th }}$ cycle) will also still be used in the core to form of the equilibrium core.

In in-core fuel management, in order to form the equilibrium core, the fuel assembly used a various enrichment of $\mathrm{UO}_{2}$ in the initial (first cycle) core, and then reshufle at the next cycle. The fresh fuel will always be added at the edge position of the core. Based on the enrichment of $\mathrm{UO}_{2}$, the fuel assemblies $2.35 \mathrm{w} / \mathrm{o}, 3.40 \mathrm{w} / \mathrm{o}$ and $4.45 \mathrm{w} / \mathrm{o}$ have average burn-ups of $21.94 \mathrm{GWD} / \mathrm{MTU}, 23.53$ GWD/MTU and 14.60 GWD/MTU, respectively. 


\section{Heavy Transuranic Nuclide}

The average fuel burn-ups and transuranic nuclide contents in each type of fuel assemblies are produced from the first operating cycle of AP1000 core showed at the Table 3. At the end of the operating cycle of the first AP1000 core, not all of the uranium fuel (U-235 and U-238) are burned, they still remains in the core. The amount of residual U-235 depending on the discharge burn-up and fuel enrichment when loading. The fuel assemblies that are not used any more can be reprocessed to make the new type fuel mixing uranium and plutonium oxide, called mixed oxide (MOX) fuel.

The transuranic nuclides contained in each type of the fuel assemblies also shown in Table 3. Those table shows that the mass composition of transuranic heavy nuclides in all type of the fuel assemblies are almost in the same. In the orderly manner, the transuranic heavy nuclides most produced consecutively is $\mathrm{Pu}, \mathrm{Np}, \mathrm{Am}$ and $\mathrm{Cm}$ which each have an atomic number 94, 93, 95 and 96. $\mathrm{Np}-239$ has a very short half-life that is approximately 2.4 days, it means it decays by emitting $\beta$-rays into Pu-239 atom quickly .

Table 3. Transuranic Nuclide Composition in the Fuel Assembly from First Cycle of AP1000

\begin{tabular}{|c|c|c|c|c|c|c|c|c|c|c|}
\hline No & & 1 & 2 & 3 & 4 & 5 & 6 & 7 & 8 & 9 \\
\hline $\begin{array}{l}\text { Nama } \\
\text { FA }\end{array}$ & & FA1 & FA1a & FA2 & FA2a & FA2b & FA3 & FA3a & FA3b & FA3c \\
\hline $\begin{array}{l}\text { Jml. } \\
\text { IFBA }\end{array}$ & Unit & - & 28 & 88 & 28 & 44 & 88 & 72 & 88 & 112 \\
\hline $\begin{array}{l}\text { Jml. } \\
\text { Pyrex }\end{array}$ & Unit & - & - & 24 & 24 & 24 & 12 & 24 & 9 & - \\
\hline \multirow[t]{2}{*}{ Burn-up } & $\%{ }^{235} \mathrm{U}$ & 72.84 & 61.40 & 58.63 & 56.15 & 56.05 & 42.49 & 28.26 & 22.38 & 36.82 \\
\hline & GWD/MTU & 25.02 & 18.86 & 23.10 & 24.48 & 23.01 & 20.16 & 12.22 & 9.29 & 16.71 \\
\hline U-235 & $\mathrm{g} / \mathrm{FA}$ & 8.038 & 11.421 & 18.82 & 17.71 & 18.77 & 40.197 & 32.226 & 43.495 & 35.398 \\
\hline U-238 & $\mathrm{g} / \mathrm{FA}$ & 1203.4 & 1210.0 & 1193.7 & 1192.7 & 1194.1 & 1191.1 & 1184.7 & 1194.4 & 1188.9 \\
\hline $\mathrm{Np}$ & $\mathrm{g} / \mathrm{FA}$ & 0.832 & 0.706 & 0.771 & 0.797 & 0.766 & 0.502 & 0.671 & 0.450 & 0.560 \\
\hline $\mathrm{Pu}$ & $\mathrm{g} / \mathrm{FA}$ & 9.981 & 8.498 & 10.46 & 10.67 & 10.33 & 6.176 & 9.457 & 4.883 & 7.336 \\
\hline $\mathrm{Am}$ & $\mathrm{g} / \mathrm{FA}$ & 0.075 & 0.030 & 0.040 & 0.047 & 0.038 & 0.003 & 0.015 & 0.001 & 0.009 \\
\hline $\mathrm{Cm}$ & $\mathrm{g} / \mathrm{FA}$ & 0.02 & 0.006 & 0.009 & 0.011 & 0.009 & $3 \mathrm{E}-4$ & 0.003 & $6 \mathrm{E}-5$ & 0.002 \\
\hline
\end{tabular}

\section{Uranium \& Plutonium Nuclide}

The process of reduction of uranium-235 nuclide and the growing of plutonium nuclides are shown in Figure 4. In the Figure 4 (a) is shown the calculation result from reference data that calculated using SCALE6.0 code [1], while Figure 4 (b) the calculations results using the SRAC2006 code.

It is clearly shown that the results of calculations using SRAC2006 shows the similar phenomena to the reference data. From the two pictures, it can be seen that a natural phenomenon occurs at the PWR during reactor operation resulted in a decrease of amount of uranium and the growing of producing plutonium. The amount of U-238 was reduced consistently with a straight line, while U-235 reduces with operating time to form a slightly curved line approaches a straight line. These two phenomenon are caused by the amount of U-238 (an average of $96.6 \mathrm{w} / \mathrm{o}$ ) in the fuel much more than U-235 (an average of $3.40 \mathrm{w} / \mathrm{o}$ ). Additionally, the fission cross-section of U-235 is larger than the absorption cross section U-238. It makes that after going through about half of the discharge burn-up, the reaction rate of U-235 would be slightly declined. The production of plutonium nuclides $\mathrm{Pu}-239$ and $\mathrm{Pu}-241$ as a fissile nuclide follows chemical reaction formula below.

$$
U 238 \stackrel{(n, \gamma)}{\longrightarrow} \bullet \stackrel{\beta-\text { decay }}{\longrightarrow} N p 239 \stackrel{(n, \gamma)}{\longrightarrow} P u 239 \stackrel{(n, \gamma)}{\longrightarrow} P u 240 \stackrel{(n, \eta)}{\longrightarrow} P u 241
$$




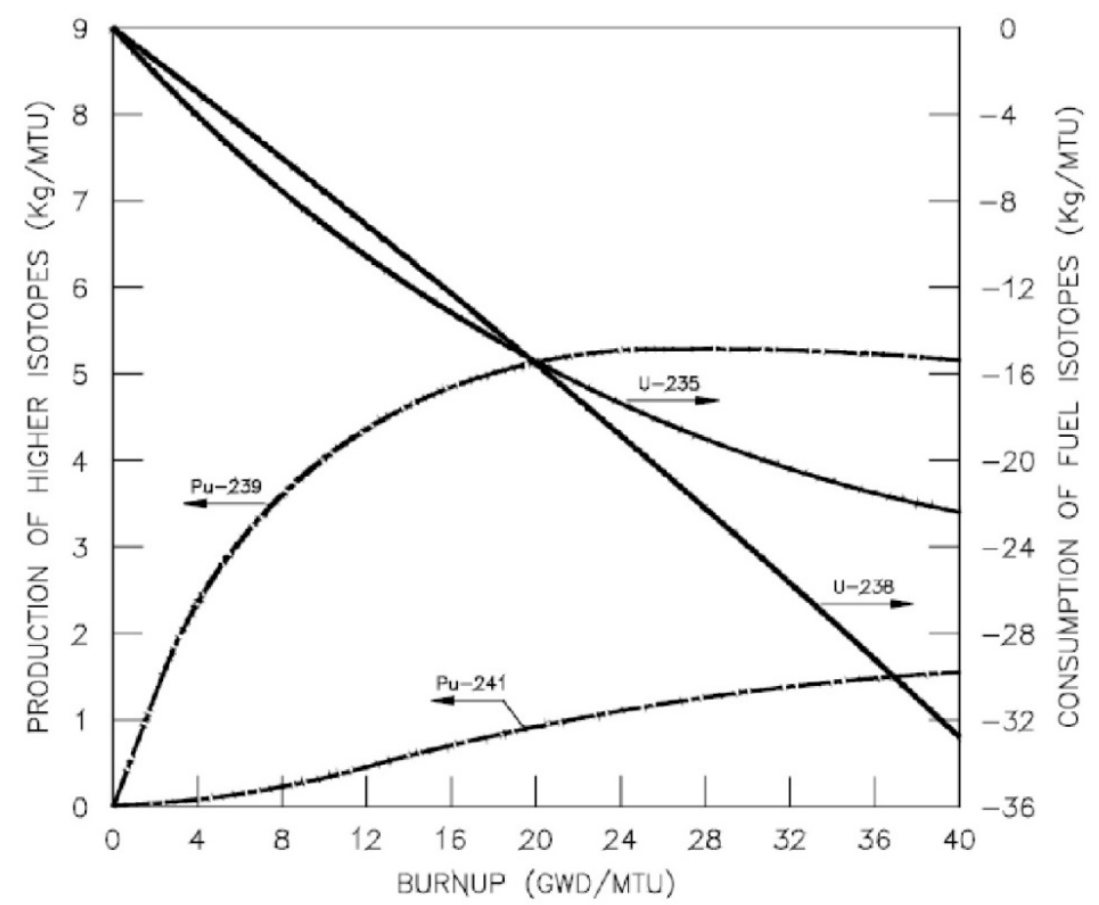

a. Reference Data [1]

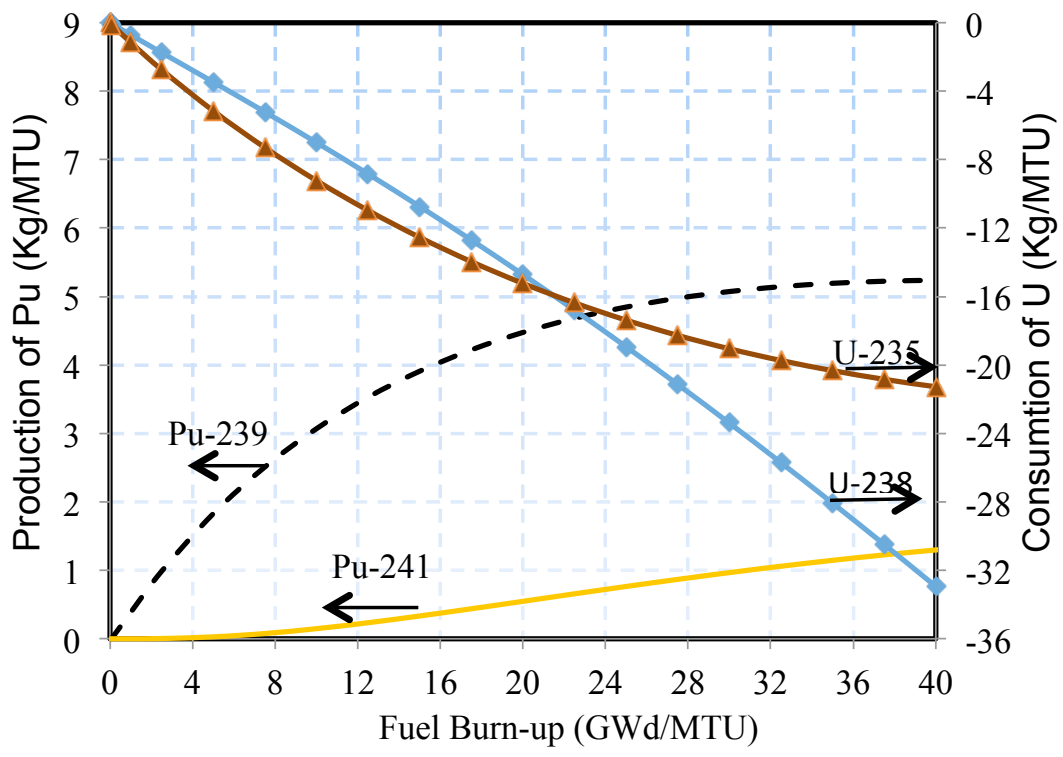

b. Calculation Result Using SRAC2006

Fig. 4. Changing of Uranium and Plutonium Nuclide Due to Fuel Burn-Up

As shown in Figure 4, Pu-239 is produced more much than $\mathrm{Pu}-241$. The U-238 absorbs neutrons then followed by $\beta$ decay will produce nuclides Np-239 and $\gamma$ rays. Np-239 absorbs a neutron to produce $\mathrm{Pu}-239$. $\mathrm{Pu}-239$ absorbs a neutron to produce nuclides $\mathrm{Pu}-240$. $\mathrm{Pu}-240$ absorbs a neutron to produce nuclides $\mathrm{Pu}-241$. Microscopic capture cross section $\left(\sigma_{\mathrm{a}}\right)$ and fission $\left(\sigma_{\mathrm{f}}\right)$ of $\mathrm{Pu}-239$ is 269.3 barns and 748.1 barns, while for $\mathrm{Pu}-241$ atom is 362.1 barn and 1011.1 barns. Because the Pu-239 which is firstly formed, have a very longer half life time than half life time of Pu-241, then it will automatically have a larger amount than $\mathrm{Pu}-241$. Based from those figure, $\mathrm{Pu}-239$ atom has a 
saturation point where the amount is relatively constant over the past $25 \mathrm{GWD} / \mathrm{MTU}$. That is caused during the formation, $\mathrm{Pu}-239$ also accour fission reaction with neutrons. So that the equilibrium is reached between plutonium produced from uranium and reduced by fission reaction.

\section{CONCLUSION}

The distribution of fuel burn-up and content of transuranic nuclides produced in the first operating cycle of AP1000 core had been successfully calculated and the analysis shows a consistent result compare to reference data. It mean the model developed in this analysis is found appropriate. The highest burn-up of fuel assemblies (27.04 GWD / MTU) is still far below the the maximum allowed burn-up (62 GWD/MTU). The use of fuel IFBA give slightly lower effect on burn-up and transuranic nuclides produced. In addition, the position of the loading of the fuel assemblies in the middle of core will produce burn-up fuel and transuranic nuclides little greater than the edge of the core. The calculation result of plutonium nuclides production and uranium consumption using SRAC2006 during operation of the reactor core shows the consitent result with reference data.

\section{ACKNOWLEDGMENT}

This study is funded by DIPA of the Center for Nuclear Reactor Technology and Safety with support financially through government budget for the year 2015. Authors also would like to express our sincere gratitude to Prof. Drs. Surian Pinem, M.Sc. and Ir. Iman Kuntoro for priceless discussion.

\section{REFERENCES}

1. Anonim. AP1000 Design Control Document Revision 18. Chapter 4.3 Nuclear Design. Available from ; http://www.nrc.gov/docs/ML1034/ML103480532.pdf. Accessed June, 2016.

2. D. Haas, D.J. Hamilton. Fuel cycle strategies and plutonium management in Europe. Progress in Nuclear Energy 2007; 49:574-582

3. Bo Cao, Jun $\mathrm{Wu}$, Tongrui Yang, Xubo Ma and Yixue Chen. Preliminary Study on Nuclear Fuel Cycle Scenarios of China before 2050. Energy Procedia 2013; 39:294-299

4. Heui-Joo Choi, Dongkeun Cho, Donghak Kook, Jongwon Choi. Current status of spent fuels and the development of computer programs for the PWR spent fuel management in Korea Progress in Nuclear Energy 2011; 53(3):290-297

5. Robbert J. Fetermen. AP1000 Core Design With 50\% MOX Loading. Annals of Nuclear Energy 2009; 36:324-330

6. Jeffrey R. Secker, Beard J. Johansen, David L. Stucker, Odelli Ozer, Kostadin Ivanov, Serkan Yilmaz, E.H. Young. Optimum Discharge Burnup and Cycle Length for PWRs. Nuclear Technology 2005; 151:109-119

7. R.F. Mahmoud, M. K. Shaat, M.E. Nagy, S.A. Agamy, A. A. Abdelrahman. Burn-up credit in criticality safety of PWR spent fuel. Nuclear Engineering and Design 2014; 280: 628-633

8. Kyu-Tae Kim. Evolutionary developments of advanced PWR nuclear fuels and cladding materials. Nuclear Engineering and Design 2013; 263:59-69

9. C.E. Velasquez, R.V. Sousa, A. Fortini, C. Pereira, A.L. Costa, C.A.M. da Silva, M.A.F. Veloso, A.H. de Oliveira, F.R. de Carvalho. Spent fuel criticality and compositions evaluation for long-term disposal in a generic cask. Nuclear Engineering and Design 2014; 275:168-178 
10. S. Rong-Jiun, L. Min-Hua, L. Jenq-Horng. Quantifying the effects of depletion parameters on the PWR spent fuel reactivity based on nuclide sensitivity coefficients. Annals of Nuclear Energy 2016; 87:126-136

11. S.J. Rose, J.N. Wilson, N. Capellan, S. David, P. Guillemin, E. Ivanov, O. Méplan, A. Nuttin, S. Siem. Minimization of actinide waste by multi-recycling of thoriated fuels in the EPR reactor. Annals of Nuclear Energy 2011; 38:2619-2624

12. Anis R., Mass Changes Analysis of Fissile And Non Fissile Materials in The PWR 1000 MWe Using ORIGEN-ARP 5.1. Journal of Nuclear Reactor Technology TRI DASA MEGA 2015; 17:13-18. (In Indonesian)

13. C.J. Diez, O. Buss, A. Hoefer, D. Porsch, O. Cabellos. Comparison of nuclear data uncertainty propagation methodologies for PWR burn-up simulations. Annals of Nuclear Energy 2015; 77:101-114.

14. Keisuke Okumura, Teruhiko Kugo, Kunio Kaneko and Keichiro Tsuchihashi. SRAC2006; A Comprehensive Neutronics Calculation Code System. JAERI-Data/Code 2007-004, January 2007, Japan Atomic Energy Agency

15. Jati S., Iman K.. Validation of COREBN / HIST Computer Code for Fuel Burn-Up Calculations and Fuel Management of RSG - GAS Core. Jurnal of Nuclear Reactor Teknologi TRI DASA MEGA 2007; 9:119-131. (In Indonesian) 